\title{
Mabuk (di) Indonesia : Membongkar Struktur di Balik Fenomena Korban Tewas Karena Oplosan
}

\author{
Rio Heykhal Belvage \\ Peneliti Independen \\ rio.belvage@gmail.com
}

\begin{abstract}
Discussing alcohol, many dimensions will likely to involve: social, history, culture, politics, economy and literature. Like rubbing salt into the wounds, the government stakeholders and media use bootleg liquor (oplosan) as a proof to their rational misconception to corner the victims or communities, saying that they have "low awareness of the danger of alcohol." It seem that they, the government and media, ignore its intricate structures which enable those deadly liquors to flare. This paper, therefore, would like to observe broader picture of the reality of alcohol in a society, focusing on the ignored dimensions of dominant discourse.
\end{abstract}

Keywords : Alcohol, culture, rationality, bootleg liquor (oplosan)

\begin{abstract}
Abstrak
Banyak dimensi mencakup sosial, sejarah, budaya, politik, ekonomi, bahkan merentang hingga sastra saat membicarakan minuman beralkohol. Namun, ibarat sudah jatuh dilempari batu, dalam satu dasawarsa terakhir kabar kematian akibat minuman alkohol oplosan justru kerap diperlakukan sebagai ajang pembuktian terhadap rasionalitas yang telah dibangun oleh lembaga-lembaga berwenang, pemangku kebijakan dan media untuk menyudutkan korban/masyarakat dengan menggunakan dalih 'rendahnya kesadaran masyarakat akan bahaya alkohol'. Sementara, struktur ruwet yang memungkinkan mengapa minuman mematikan itu bisa marak tidak pernah diungkap. Tulisan ini ingin melihat lebih dalam gambaran realitas pada dimensi-dimensi yang selama ini telah diasingkan sedemikian rupa oleh diskursus dominan itu.
\end{abstract}

Kata kunci : Minuman beralkohol, budaya, rasionalitas, oplosan

\section{Pendahuluan}

Saat wacana minuman keras dan korban minuman oplosan mengemuka jadi bahan gunjingan publik terdapat beberapa dimensi yang tidak banyak diungkap. Seperti diketahui dari berbagai pemberitaan di media, dari tahun ke tahun, berita tentang razia minuman keras di Indonesia rutin tayang menjadi perbincangan publik. Dari tahun ke tahun itu pula, pihakpihak yang dianggap punya wewenang untuk bicara di depan publik dari mulai ahli psikologi, sosiolog, ahli medis serta lembaga lain yang bergerak pada isu tersebut, berbicara tentang bahayanya minuman keras. Namun, jika dicermati, semua perbincangan itu 
memiliki nada yang sama: minuman keras adalah minuman yang harus dibatasi, atau bahkan dilarang peredarannya. Tapi benarkah sesederhana itu?

Di dalam tulisan ini saya berargumen bahwa permasalahan tentang minuman keras di Indonesia tidaklah sesederhana soal pelarangan sebagaimana wacana yang tampil di media. Lebih jauh lagi, ketika minuman keras itu kemudian mengakibatkan kematian dalam jumlah yang tidak sedikit dari tahun ke tahun, pihak-pihak yang dianggap ahli dalam soal medis, kejiwaan maupun sosial, masih saja menanggapi gejala itu dengan isi pembicaraan yang melulu sama, bahwa minuman keras mesti dilarang, dibatasi dan lain sebagainya.

Hal yang mengganjal benak saya sebagai pembelajar antropologi adalah wacana minuman keras yang beredar selama ini sama sekali tidak mengungkit dimensi historis, budaya, ekonomi dan politik. Seolah keberadaannya adalah cermin retak yang jika dipasang akan memampang wajah buruk, dan bukan itu yang dikehendaki wacana tentang minuman keras. Sementara di saat yang sama, kabar orang tewas karena menenggak oplosan masih terus terdengar. Artinya, ada yang janggal dalam hal ini. Pada kejanggalan semacam itulah yang mendorong saya untuk menunjukkan dimensi lain yang tak banyak diungkap atau mungkin juga kurang populer namun sebenarnya lekat dengan keseharian, tulisan ini sekaligus ingin menunjukkan bahwa apa yang kerap dialienasi oleh lembagalembaga penjaga moral tak lain adalah sesuatu yang lekat dengan "kedirian manusia Indonesia”, dengan identitas dan ragam budaya manusia Indonesia, yang jika dialienasi, maka hal itu juga berarti mengalienasi kedirian manusia Indonesia itu sendiri.

\section{Kajian Pustaka}

Jika berkaca pada sejarah, maka riwayat minuman beralkohol lebih tua dari usia Indonesia. Tetapi sejak dipopulerkannya kosakata itu oleh etnolog Adolf Bastian dan digunakan sebagai nama ganti negara baru setelah Hindia-Belanda, rupanya nasib minuman itu kian berlawanan dengan prosedur menjadi manusia Indonesia yang baik dan benar. Kisah pelarangan demi pelarangan terhadap Lapen, Ciu, Arak dan beragam jenis minuman produksi lokal lain di banyak tempat (yang mungkin sebagian sudah punah) membuat minuman tersebut seolah sudah lumrah untuk disalah-salahkan. Padahal jika menengok lagi ke belakang, regulasi minuman produksi lokal yang mengandung kadar alkohol dewasa ini justru mengesankan negara yang tidak mampu mengenali keberagaman bangsanya sendiri (Perbedaan antara negara dan bangsa salah satunya dapat ditemukan di tulisan Benedict Anderson "Old State New Society: Indonesia's New Order in Comparative Historical Perspective”, yang terjemahannya ke dalam bahasa Indonesia dapat dijumpai di media internet berjudul “Negara Kolonial dalam Baju Orde Baru”).

Cerita betapa tua minuman beralkohol dari usia Indonesia barangkali dapat ditemukan dalam jejak kisah dewa-dewi dan Mulajadi Nabolon di Banua Ginjang (kayangan) pada legenda yang hidup di balik pohon aren (bagot) dalam masyarakat Batak. Narasi Sumirat Lohjati (2011) dalam "The Art of Drinking” menceritakan bahwa jenis minuman tuak (Palm Wine) telah melebur dalam kehidupan kultural sehari-hari masyarakat Batak, terutama di dataran tinggi - dan saya menjumpai sendiri apa kata Lohjati tersebut ketika suatukali melakukan penelitian di sana. Di daerah itu dengan mudah dijumpai banyak berdiri lapo atau kedai (bahkan oleh masyarakat setempat nama lapo juga biasa diplesetkan sebagai "lapangan politik", artinya ia tidak sebatas tempat minum-minum belaka, melainkan menjadi ruang publik tempat 
komunikasi berlangsung sebagaimana dibayangkan Habermas tentang demokrasi deliberatif). Palm Wine diklasifikasi ke dalam dua jenis, pertama tuak tangkasan yang selalu diikutsertakan sebagai minuman dalam prosesi adat, dan kedua tuak na tonggi yang umumnya dikonsumsi oleh kaum wanita - walaupun banyak pula kalangan pria yang juga menggemarinya. Untuk tuak na tonggi, orang Batak meyakini bahwa barangsiapa perempuan yang setelah melahirkan meminum air berwarna putih itu (di Yogyakarta, kaum muda menyebutnya sebagai Susu Macan), dapat membantu memperlancar produksi air susu bagi si jabang bayi. Fermentasi minuman berkadar alkohol yang kini kerap menelan nyawa itu, di dalam sistem pengetahuan lokal justru memiliki fungsi kesehatan dan bukan hanya memabukkan.

Bila di Batak tuak begitu menyatu dengan kehidupan kultural, maka pada orang Bali dan masyarakat di luarnya, jenis arak mungkin lebih "meng-Indonesia" setelah grup band Slank merilis lagu "Bali Bagus” di mana sang vokalis mengungkapkan terima kasih atas kerasnya arak Bali melalui lagunya. Tetapi jauh sebelum itu arak memang telah menjadi bagian dari uborampe dalam prosesi adat Bali. Hal serupa dapat ditemukan juga pada beberapa masyarakat Dayak di Kalimantan dalam gawai atau pesta-pesta adat. Pada masyarakat Jawa seperti Tuban dan daerah sekitarnya di utara Jawa, minuman itu bahkan telah lama identik dengan seni pertunjukan masa lalu yang kini sudah nyaris punah lantaran kalah populer dengan dangdut koplo, sebut saja beberapa kesenian seperti Ledhek, Tayub, Ronggeng dan Tandhak Ngamen. Arak dan tuak, di sini, berfungsi menjadi minuman penggembira, pemeriah yang menghilangkan rasa canggung dan menghadirkan nuansa kebersamaan yang cair.

Mengenai kedekatan minuman dan seni pertunjukan tradisional itu, Henri Supriyanto (2012) dalam tulisannya memberikan gambaran mendetail dalam salah satu seni Tandak Ngamen. Konon di dalam pertunjukan para penari yang mendapat kalungan kain sampur dari pengunjung wajib ngibing (menari di panggung tarian) bersama si pemberi kain. Pergantian penari pun diatur dalam gendhing (lagu gamelan Jawa) yang entah mengapa mengingatkan saya pada ritual tari-tarian orang modern (dugem) di mana untuk mendapat teman ajojing di lantai dansa, seseorang biasanya akan mendatangi lawan jenis yang disukainya dan menawarkan sesloki minuman sebagai tanda ajakan untuk berjoget bersama. Bedanya, pada tarian tradisional itu dikenal istilah "sawer", di mana si laki-laki yang mengalungkan sampur ke leher sang penari, akan menyelipkan lembaran uang kertas kepada penari “di dompet tradisional” (biasanya di sela-sela belahan buah dada perempuan). Sementara pada gendhing berikutnya, penari yang hendak ngibing, terlebih dahulu diberi sesloki minuman untuk pembangkit keberanian saat menari.

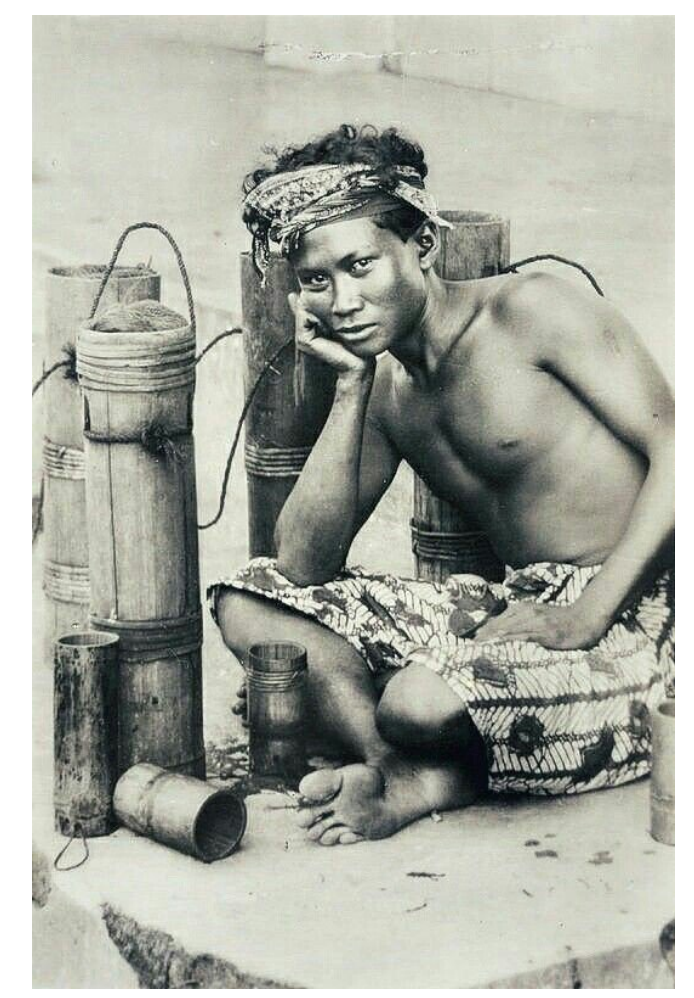

Keterangan gambar : penjual tuak di Hindia Belanda, tahun 1930 (Sumber : akun twitter @HistoriDunia) 
Jauh sebelum masa-masa itu, sebagaimana ditulis Paring Waluyo Utomo (2012), dikisahkan pada abad 11 Masehi, konon seusai bala tentara Tar-Tar dari Mongolia berhasil mengalahkan bala tentara Kerajaan Daha (Kediri), mereka kemudian singgah di Tuban untuk merayakan kemenangan dengan pesta tuak dan arak. Di masa Kerajaan Singasari, sejarawan Earl Drake (2012) menuturkan bagaimana raja bernama Kertanegara, karena terpengaruh oleh aliran ritual tantra, biasa menenggak tuak dan ngeseks. Sembari menyitir keterangan dari Kitab Paraton bab kelima yang mengisahkan raja bersama mahapatihnya mabuk tuak di bangsal perempuan, Drake menulis;

“Tantra berarti 'menenun'.., sebuah ritual rahasia Tibet yang dilakoni justru dengan menghadapi apa yang selama ini dihindari.., sejumlah peserta mengikuti ritual dengan taat untuk menguji kemampuan mereka menahan godaan nafsu duniawi demi meraih jalan pencerahan. Dalam ritual itu beberapa merasa malu atau malah terangsang oleh kenikmatan alkohol dan seks.., sejumlah laki-laki berpasangan dengan gadis muda menawan - atau yoginis, yang diboyong dari Champa, dan sebelumnya sudah dilatih sebagai pelaku tantra..(Earl Drake, 2012: 11-13)”.

Melalui tulisan Drake di atas, kita memperoleh sedikit gambaran tentang masa lalu bahwa setidaknya bukan hanya minuman beralkohol saja yang hari ini terdengar 'amoral', bahkan diskursus seksualitas yang selalu direpresi oleh moralitas dominan sekaligus dikomodifikasi dalam dunia industri, ternyata ratusan tahun lalu oleh sebagian kelompok petinggi negeri justru dianggap sebagai bagian dari ritual suci sebagai jalan mencapai pencerahan. Kasijanto (2006) juga mencatat, dalam naskah Nagarakertagama yang ditulis pada zaman keemasan Majapahit, diketahui bahwa minuman beralkohol selalu menjadi bagian dari perjamuan agung di kerajaan. Tentu jika dilihat dari kacamata hari ini, itu adalah sebuah kebiasaan 'nyleneh' yang hanya dapat diterima oleh logika kehidupan "Jakarta Undercover" pada cerita Moammar Emka, dimana seksualitas dan alkohol menjadi media pemenuhan hasrat manusia kota. Tanpa bermaksud mengunggulkan masa yang sudah lama lewat, keterangan sejarah ini dengan sendirinya telah menunjukkan bahwa apa yang kerapkali kita bayangkan sebagai tindakan 'amoral' dan kemudian kita lawan habishabisan seturut dengan rasionalitas modern masyarakat masa kini, bukanlah suatu hal yang baru.

Terbentuknya organisasi Gerakan Nasional Anti Miras (GENAM) yang dideklarasikan pada tanggal 1 September 2013 dengan slogan "Menyelamatkan generasi muda Indonesia dari bahaya minuman beralkohol dan minuman keras”, akan mengingatkan pada beberapa lembaga dengan spirit serupa yang banyak bermunculan dalam masa politik etis seabad silam. Sebagaimana diterangkan Kasijanto (2006), salah satu hasil keputusan Kongres Sarekat Islam (SI) tahun 1915 menyerukan kepada pihak pemerintah kolonial supaya memberlakukan undang-undang untuk melarang anak negeri menggunakan minuman beralkohol. Keputusan itu juga disusul oleh pernyataan Muhammadiyah di Yogyakarta yang menginginkan agar pemerintah memberlakukan sistem monopoli perdagangan minuman keras seperti halnya yang dilakukan pada perdagangan candu. Sikap serupa pun datang dari organisasi Boedi Oetomo yang mendesak pihak pemerintah agar membatasi tempat penjualan minuman keras dan mempermahal harganya dengan menaikkan cukai, dimana kebijakan tersebut diteruskan pada masa pendudukan Jepang (Osamu Seirei) dan diwarisi Indonesia melalui Undangundang No.29 Tahun 1947, yang jejaknya masih terlihat jelas di setiap perdebatan 
mengenai pengaturan minuman keras sampai hari ini.

Dalam catatan sejarah negeri ini, mau tidak mau kita memang harus mengakui bahwa minuman beralkohol, seksualitas, dan bahkan candu pernah menjadi komoditas berharga di bawah sistem pemerintahan kolonial, yang sempat juga dilanjutkan oleh negara Indonesia. Robert Cribb (1988) dalam tulisannya berjudul "Opium and the Indonesian Revolution" menyatakan bahwa dari tahun 1945 hingga 1949 penghasilan yang diperoleh Indonesia dari perdagangan candu berperan besar dalam membantu mempertahankan perjuangan melawan Belanda. Bisnis tersebut telah menyelamatkan sebuah negara baru karena pendapatan yang dihasilkannya dapat digunakan untuk mencukupi kebutuhan gaji para pegawai, terutama untuk membiayai pospos perwakilan Republik Indonesia di luar negeri dan delegasi Indonesia yang sedang berunding dengan Belanda di Jakarta. Semua perjuangan itu tentu membutuhkan biaya yang tidak sedikit jumlahnya. Dan itulah mengapa selain melalui perang berdarah-darah dan perundingan, revolusi Indonesia diam-diam juga berhutang pada jenis perdagangan yang sulit diterima oleh rasionalitas zaman sekarang. Pada bulan September 1945, setelah pemerintah Jepang menyerahkan penguasaan pabrik candu di Salemba, negara Indonesia mendirikan kantor Djawatan Tjandoe dan Garam yang pada tahun berikutnya tidak saja telah mampu mendistribusikan candu untuk dikirim ke daerah-daerah lain seperti dari Yogyakarta ke Jepara, tetapi juga telah membawanya ke pelabuhan dagang di Singapura untuk bersaing dengan barang dari negara lain. Gambaran ini sedikitnya mengingatkan pada kepemilikan saham perusahaan bir oleh pemerintah provinsi DKI Jakarta sejak tahun 70'an, yang di tahun 2014 menjadi penyumbang Pendapatan Asli Daerah (PAD) terbesar ketiga sejumlah 50 miliar, tetapi baru asyik dipergunjingkan pada tahun 2015 berkat bombardir industri media - bahkan belakangan, di tahun 2018, wacana itu mulai menyeruak kembali di bawah pemerintahan gubernur yang baru. Di sinilah seringkali kemudian dimensi-dimensi moral sosial bertabrakan dengan dimensi ekonomi, sebuah tabrakan yang terus memproduksi korban dengan menelan nyawa masyarakat kelas bawah.

\section{Metode}

Tulisan ini menggunakan perspektif paskastrukturalis, dengan berpijak pada alur berpikir Foucault-ian. Dalam alur berpikir Foucaultian - khususnya jika memperhatikan salah-satu karya Foucault (2002) yang berjudul “Kegilaan dan Peradaban”, pada buku itu ia menjabarkan bagaimana proses pengetahuan dan kekuasaan setali tiga uang dalam melahirkan masyarakat yang teralienasi, dan bahkan memproduksi satu keilmuan baru, suatu moralitas dalam suatu zaman yang terusmenerus dihidupi. Berangkat dari karya Foucault itu, serta maraknya orang tewas karena minuman oplosan yang sangat mengusik nurani, saya mulai memetakan formasi diskursif yang membentuk wacana mengenai minuman keras dan minuman oplosan.

Tentu saja metode penelitian yang digunakan di tulisan ini tidak seketat metode pada umumnya, karena pada dasarnya Foucault sendiri tidak pernah secara eksplisit menampilkan metodenya. Akan tetapi jika berangkat dari perspektif Foucaultian, tentunya ada beberapa konsep yang umum digunakan yang berkonsentrasi pada satu kata kunci: kekuasaan. Yang dimaksud sebagai kekuasaan di sini, sebagaimana diterangkan Haryatmoko (2016); "Bukan suatu institusi, dan bukan struktur, bukan pula suatu kekuatan yang dimiliki; tetapi nama yang diberikan pada suatu situasi strategis yang kompleks dalam suatu masyarakat.., Kekuasaan ada di manamana; bukannya bahwa kekuasaan mencakup semua, tetapi kekuasaan datang dari mana- 
mana”. Selain kekuasaan, Foucault juga menawarkan konsep tentang "relasi pengetahuan”, "biopolitik”, "genealogi”, "governmentality". Konsep-konsep tersebut yang biasa digunakan untuk memahami "negativitas” kebudayaan, suatu wilayah yang kerap dianggap “abu-abu” atau tabu untuk diperbincangkan. Melalui tema yang saya angkat dalam tulisan ini, saya lalu menjahit beberapa konsep di atas menggunakan studi literatur tentang sejarah, sastra, berita di media, yang juga diperkuat dengan data lapangan.

\section{Hasil dan Pembahasan}

\section{(P)ujian Sepasang Pemabuk}

"Mereka duduk bermalas-malasan di sofa. Marno dengan segelas scotch dan Jane dengan segelas martini. Mereka sama-sama memandang ke luar jendela.”

Alih-alih mengulang kesan orang terdahulu tentang cerita pendek (cerpen) "Kunangkunang di Manhattan”, katakanlah seperti Korrie Layun Rampan yang memuji tulisan Umar Kayam sebagai wujud dari sastra suasana dengan teknik bercerita yang sederhana, atau Jacob Sumardjo yang menyebut cerita itu mampu mengangkat suasana batin manusia, saya lebih tertarik untuk melihat kemungkinan lain tentang mengapa suasana dapat hadir begitu kuat dalam cerita pendek (cerpen) itu. Potongan kalimat yang saya cantumkan di atas adalah bagian awal cerpen Umar Kayam. Ia mengawali ceritanya dengan memperkenalkan tokoh yang sedang berinteraksi dengan minuman beralkohol. "Marno dengan segelas scotch dan Jane dengan segelas martini”. Dilihat sepintas dari mereknya, minuman tersebut tidak saja tergolong "mahal" tetapi juga asing untuk orang desa yang terbiasa meminum minuman hasil olahan masyarakatnya sendiri.
Kehidupan bohemian yang dihadirkan oleh Umar Kayam dalam ceritanya justru terasa kuat meski tulisan itu sendiri telah berumur setengah abad, karena penyebutan dua jenis minuman itu sampai hari ini masih dapat dijumpai: scotch dan martini. Marno dan Jane, sepasang lawan jenis yang dikisahkan sedang mabuk di sebuah apartemen di jantung kota dunia, sebuah kondisi - yang bila boleh dikata, menduduki imajinasi ideal di sebagian besar kehidupan manusia kota. Namun meskipun terbilang ideal, rupanya Umar Kayam tidak membiarkan tokohnya larut begitu saja dalam “cinta murahan”. Ia tidak membiarkan Marno yang sudah mabuk lalu tidur dengan Jane meskipun Jane sendiri telah memberikan isyarat kepada Marno dengan memberikan piyama untuknya, "Kau pakai saja malam ini. Aku kira sekarang sudah cukup malam untuk berganti dengan piyama”. Penolakan Marno untuk memenuhi undangan tidur di tempat Jane itulah yang menjadi kekuatan lain dalam cerita Umar Kayam. Tokoh yang dihadirkannya dibentuk sedemikian rupa agar menolak realitas "yang seharusnya terjadi" dengan membuat Marno tiba-tiba teringat istrinya dan memilih untuk pulang.

Tidak hanya dalam pembukaan cerita saja Umar Kayam memperkenalkan minuman beralkohol, tetapi juga pada bagian penutupnya. Cerita dibuat menggantung seolah belum selesai, dengan menyisakan kejanggalan pada diri Jane yang ditinggal pulang oleh Marno. Dalam keadaan mabuk pada akhir cerita, "Di kamarnya, di tempat tidur sesudah minum beberapa butir obat tidur, Jane merasa bantalnya basah”.

Akan keliru bila kita serta-merta mengira obat tidur yang diminum Jane berfungsi untuk membuatnya lekas pulas. Sebab adegan meminum beberapa butir obat tidur setelah menenggak alkohol itu juga bisa berarti Jane yang sedang mencoba bunuh diri dalam kesedihan, karena obat tidur bisa menambah dosis teler dari minuman beralkohol. Tetapi itu 
hanya tafsir. Meskipun ada yang jauh lebih menarik dari itu.

Hal menarik itu terletak pada dunia pembaca. Jika minuman beralkohol memang bertentangan dengan nilai-nilai moral masyarakat sebagaimana tertera dalam diskursus dominan selama ini, lalu mengapa bisa banyak pembaca Indonesia menyanjung karya yang sudah jelas menampilkan gambaran orang mabuk? Bagaimana mungkin melarang minuman beralkohol, tetapi di saat yang sama minuman itu dapat bebas beredar di wilayah sastra, bahkan sampai mendapat penghargaan sebagai cerpen pilihan terbaik pada masanya? Bagaimana menjelaskan hal semacam ini?

Bila keluar dari wacana dominan tentang minuman beralkohol dan memasuki beragam dimensi lain seperti sastra misalnya, kita akan sampai pada perbincangan bahwa membahas minuman beralkohol tidaklah melulu urusan larang-melarang. Memasuki sastra dalam narasi di atas, kita akan dibawa masuk pada dinamika kehidupan itu sendiri. Di dalamnya kita tidak lagi sekedar berbincang soal standarisasi nilai, aliran, teknik bercerita dalam penulisan yang digunakan untuk mencapai keindahan, tetapi juga diajak untuk mengalami sendiri bagaimana memahami pembebasan dalam proses pembacaan, merasakan perjuangan tiap-tiap karakter untuk terbebas dari alur konflik yang didesain oleh pengarang. Apakah suasana mabuk merupakan keindahan, atau kesalahan?

\section{Melihat Lebih Dekat}

Pada umumnya pemahaman tentang minuman oplosan selama ini diambil dari subyek pelaku. Subyek pelaku, diobyektifikasi oleh diskursus dominan seperti hukum, media, kesehatan dan mungkin juga agama (saya menyebut semua itu sebagai konfigurasi rasionalitas modern). Oleh karena itu bagian ini tidak saja akan menghadirkan dimensi pemuda dan pemabuk dari dunia yang dialaminya, tetapi juga akan menceritakan fragmen kehidupan nelayan dan dunia yang mungkin membingungkan bagi rasionalitas modern, serta juga akan menampilkan hubungan antara alkohol dan politik. Cerita kaum muda mewakili liminalitas yang tersegmentasi oleh usia dimana diskursus dominan lebih banyak menggambarkannya sebagai "fase labil" dan sensitif terhadap perubahan di lingkungan pergaulan. Sementara penghadiran kehidupan nelayan mewakili kondisi sosio-kultural masyarakat terkait kedekatannya dengan minuman beralkohol, dan bagian terakhir tentang alkohol dan politik adalah untuk mengangkat ke permukaan fakta yang selama ini agaknya tak begitu diperhatikan setiapkali membicarakan persoalan mengenai pemberantasan minuman tersebut.

\section{Kaum Muda dan Minuman}

Sewaktu saya masih duduk di bangku kelas tiga SMA, antara tahun 2006 dan 2007, ada jenis minuman alkohol terbaru seharga Rp.12.500,00 bernama Newport. Mungkin karena kebaruannya minuman itupun cepat mendapatkan pelanggan. Harganya sendiri lebih murah dari minuman lain sejenis yang bermerek Kuntul dan setara dengan harga minuman cap Anggur Merah, walau jika dibandingkan dengan Vodka dan Wishky, sama sekali tidak ada apa-apanya. Untuk Vodka dan Wishky dalam varian botol kecil saja harganya Rp.25.000,000, pas dua kali lipat banyaknya dari harga minuman merek Newport. Selain merek-merek itu, ada juga minuman produksi buatan sendiri yang tentu saja tanpa label departemen kesehatan (depkes) yang dijuluki “Baceman”. Dalam bahasa sekarang lebih dikenal dengan sebutan oplosan. Karena buatan sendiri, harga minuman Baceman pun bisa jauh lebih murah jika dibandingkan dengan minuman berlabel depkes. Misalnya, bila uang Rp.12.500,00 dibelikan Newport hanya mendapat satu botol (1liter), maka jika itu dibelikan Baceman 
paling tidak akan mendapatkan 2liter. Dua kali lipat lebih banyak dari minuman berlabel depkes. Soal rasa, jangan ditanya. Bagi yang terbiasa minum-minuman mahal (enak/aman) pasti akan langsung memuntahkan semua yang ia minum saat baru mencicip rasa Baceman.

Di samping minuman beralkohol, ada jenis obat-obatan seperti dextro, lexotan, persik, dan bahkan beberapa jenis obat tidur juga marak dikonsumsi dalam dosis tinggi. Tetapi hanya orang-orang tertentu saja yang berani menggunakan ini, karena selain menggunakan obat-obatan bisa berurusan langsung dengan pihak kepolisian, juga mendapat celaan dari sesama kawan. Pendek kata ada pandangan yang terus dihidupkan di lingkungan pergaulan kalau "lebih baik mabuk minuman daripada mabuk obat, karena obat itu membikin bego”.

Inilah kontrol sosial yang terdapat di lingkungan kaum muda yang meskipun tergolong doyan mengkonsumsi minuman beralkohol, tetapi juga memiliki nilai-nilai sosial untuk melindungi satu sama lain supaya tidak terjerumus ke dalam dunia obat-obatan dan kena sanksi hukum. Walaupun begitu bukan berarti kemudian satu lingkaran pergaulan steril dari pengaruh obat-obatan. Satu kawan saya pernah tertangkap polisi saat mengantongi obat dalam keadaan mabuk. Menurut keterangan dari kawan-kawan lain, dia sebelumnya sudah sering diingatkan, tetapi memang dasarnya susah dibilangin. Akibat kebiasaannya itu dia pun mesti menginap di sel tahanan selama beberapa bulan, sebelum kemudian ditebus oleh keluarganya.

Kembali pada Newport dan kebiasaan minumminuman beralkohol. Kemunculan jenis minuman itu langsung menjadi populer dan digemari oleh kawan-kawan. Latar belakang kawan-kawan saya itu kebetulan semuanya berada setingkat di atas saya alias lebih senior, sebagian ada yang menganggur karena susah mencari kerja, sebagian lainnya lagi sedang menikmati masa jeda sebelum memasuki bangku perkuliahan. Dalam masa-masa itu, saya merasakan - seperti juga mungkin dirasakan oleh mereka yang melewati fasefase transisi, bahwa pada tahap itu memang merupakan masanya senang-senang, seruseruan.

Di lingkungan mereka yang suka minum, tidak punya uang bukan berarti tidak bisa senang (saya pikir fase ini juga dialami oleh setiap generasi ketika menginjak usia-usia transisi). Setiapkali berkumpul pada malam hari di akhir pekan, atau ketika ada hari-hari besar seperti tahun baru, masing-masing orang yang hadir dan berkumpul secara sukarela akan merogoh kocek patungan. Ada tiga ribu, ya tiga ribu. Syukur-syukur kalau ada yang sepuluh ribu. Uang yang sudah terkumpul kemudian dibelikan minuman beralkohol. Namun jenis minuman apa yang akan dibeli selalu terlebih dulu disesuaikan dengan seberapa banyak jumlah kawan yang berkumpul ketika itu. Jika yang berkumpul sedikit, katakanlah empat sampai lima orang, sementara uang yang terkumpul Rp.25.000,00, biasanya kawankawan akan memilih Newport. Tetapi bila uang yang terkumpul tetap dua puluh lima ribu sementara yang hadir sepuluh orang, minuman Bacemanlah yang menjadi pilihan. Pertimbangannya, dengan uang sejumlah itu dan jika yang hadir ada sepuluh orang, kalau dibelikan Baceman akan mendapat paling tidak 4liter, jumlah yang dirasa pas supaya semua bisa merasakan kemabukan yang dicari. Jangan membayangkan tentang Vodka atau Wishky, karena untuk seukuran remaja yang masih berseragam putih abu-abu, dua merek berkadar alkohol tinggi tersebut mahal harganya. Mereka hanya akan membelinya jika memang ada momen spesial seperti bila ada ulang tahun, yang itu juga berarti mereka akan minum merek itu jika ada yang membelikannya alias gratis.

Pada waktu itu tidak ada yang mempertanyakan, misalnya mengapa cari minuman semakin hari semakin susah saja, banyak penjual yang kemudian lebih memilih 
untuk menutup lapak dagangannya, harga minuman depkes yang tiba-tiba bisa melambung jauh di atas kemampuan mereka membelinya (sekedar gambaran kecil, jenis minuman cap Anggur Merah depkes dari yang semula harganya Rp.12.500,00 di tahun 2008, pada tahun 2014 menjadi Rp.49.000,00, nyaris mengalami kenaikan 400\% dari harga semula). Ini terjadi karena memang yang dicari oleh mereka bukan mempermasalahkan mengapa akses untuk memperoleh minuman tiba-tiba jadi sulit, tetapi lebih pada mabuknya. Yang dicari adalah momen senang-senang bersama, mabuk bersama-sama. Paling banter, kabar tentang semakin mahalnya minuman dan susahnya membeli hanya berakhir jadi gerundelan dalam obrolan tanpa tahu dimana posisi mereka di tengah fenomena tersebut.

Kalaupun sedang tidak ada uang untuk minum, kebutuhan masih bisa tertutupi dari kawan lain yang punya uang. Kalaupun minuman terlalu mahal untuk dibeli, bisa diakali dengan memilih minuman yang lebih murah, asal membuat mabuk. Kalaupun minuman paling murah sekalipun tidak bisa membuat mabuk, masih ada jalan dengan menambah dosis melalui campuran Autan (obat nyamuk) atau obat-obatan lain. Yang penting bisa tetap membikin mabuk, bisa berkumpul bersama kawan, senang-senang bersama, nyanyi-nyanyi bersama, melupakan duka-lelah sejenak.

Tanpa bermaksud untuk melakukan generalisasi dari fenomena di suatu tempat yang sudah berlalu dengan fenomena kekinian yang bila dihitung angkanya mengakibatkan tewasnya ratusan anak muda setelah minum oplosan, tetapi paling tidak dari gambaran kecil kehidupan kaum muda itu, dapat ditarik satu logika umum untuk mengetahui mengapa sekelompok orang yang gemar minum lebih memilih jenis minuman berbahaya daripada minuman yang layak dan aman dikonsumsi. Bodohkah mereka karena tak membeli minuman yang sudah jelas-jelas berbahaya? Tidak. Tak tahukah mereka apa yang mereka konsumsi bisa membunuh mereka? Bukan tak tahu, justru mereka sangat tahu itu, karena mereka pelakunya langsung. Lalu mengapa mereka tetap bersikeras membelinya? Ada suatu kondisi (kalau tak mau disebut sebagai struktur ekonomi-politik) yang mendeterminasi para peminum untuk tidak dapat keluar dari jaring-jaring situasi; keterbatasan isi dompet, munculnya aturanaturan baru terkait minuman beralkohol, pelarangan dan pembatasan peredaran, naiknya harga-harga minuman, munculnya lapak-lapak baru pembuat minuman amatir yang menjual produknya dengan harga terjangkau namun tak jelas komposisi bahannya - semua itu hanyalah sebagian kecil dari penyebab mengapa berita orang tewas setelah menenggak minuman menjadi rutinitas di Indonesia hari ini.

\section{Minuman dan Nelayan}

Pada akhir Juni 2015 saya tiba di sebuah kota industri, kawasan pesisir bagian selatan pulau Jawa. Di sebuah desa yang menurut catatan kependudukan tahun 2014 berjumlah 21.340 jiwa, 35\% warga hidup sebagai buruh nelayan di laut yang telah tercemar oleh limbah industri ekstraktif. Di sana minuman beralkohol bukanlah sesuatu yang asing. Kedekatan masyarakat dengan jenis-jenis minuman beralkohol semacam ini bukanlah sesuatu yang unik. Karena memang telah menjadi tradisi keberadaan minuman beralkohol lekat dengan kehidupan masyarakat nelayan. Bukan semata-mata digunakan untuk mabuk-mabukan, tetapi keberadaan minuman tersebut dapat berkhasiat menghalau dinginnya angin laut ketika berangkat berlayar mencari ikan pada malam hari.

Masyarakat nelayan di Cilacap mengenal dua musim yang menentukan hasil tangkapan ikan ketika melaut, dan hasil tangkapan itulah yang menentukan banyak-sedikitnya rejeki yang didapat. Along, merujuk pada saat-saat ketika tangkapan ikan banyak. Dengan hasil 
tangkapan ikan yang banyak, Along juga sekaligus menandai tingginya tingkat konsumsi nelayan. Rejeki yang didapat dari menangkap ikan akan dibelikan apa saja sejauh dapat memenuhi kebutuhan dan keinginan keluarga. Sebaliknya, ketika sedang Faila, atau musim angin timur, ikan susah ditangkap, perekonomian pun berada dalam kondisi sulit, sehingga solusi ketika Faila yang bisa dilakukan biasanya adalah dengan berhutang kepada juragan, meminjam di koperasi simpan-pinjam di desa atau ada juga yang terpaksa harus menjual harta bendanya untuk mencukupi kebutuhan hidupnya. Di tengah tantangan ekonomi yang mesti dihadapi itulah, bagi nelayan yang biasa berhari-hari atau berminggu-minggu berada di tengah laut, minuman beralkohol bukanlah suatu yang asing. Seorang warga pernah menceritakan hal tersebut ketika saya berbincang dengannya;

"Miras sulit untuk dihilangkan, karena sudah menjadi kebiasaan masyarakat sini. Pekerjaan nelayan kan di laut, dingin. Orang minum untuk menghangatkan badan. Meskipun kebiasaan itu kemudian juga sering terbawa sesampainya di darat. Itu biasa... ibaratnya sama seperti orang yang tidak terbiasa berada di laut ketika sampai di laut kemudian mabuk laut, ya begitulah..” (Catatan lapangan, 2015).

Seperti dikatakan oleh seorang warga di desa itu, minuman memang telah biasa dikonsumsi tidak hanya di laut untuk menghalau udara dingin saat sedang bekerja, tetapi juga menjadi kebiasaan yang terbawa sampai di darat, di tempat tinggalnya. Ada satu wilayah rukun warga (RW) di desa itu dimana perjudian sabung ayam marak. Ketika saya mendatangi tempat tersebut saat sedang sepi, tempat judi ayam itu terlihat dibuatkan gazebo supaya penjudi yang hadir terlindung dari hujan dan panas. Tidak jauh dari tempat itu terdapat warung kecil yang menjual rokok dan makanan ringan. Di sanalah mereka yang biasa minum alkohol dan gemar berjudi, mendapatkan tempat yang tepat.

Di salah satu sudut desa yang hanya berjarak beberapa ratus meter dari laut, sebagian penjudi bukanlah berasal dari desa itu sendiri, tetapi justru dari kota. Setiapkali pihak aparat kepolisian melakukan razia hendak menertibkan tempat itu, penjudi selalu lolos. Tak lain karena selalu mendapat bocoran lebih dulu jika akan ada razia. Menurut cerita yang saya himpun dari warga sekitar saat berada di sana, para penjudi itu banyak yang berasal dari luar daerah dan beberapa di antara mereka adalah tentara yang punya pangkat dan berpengaruh. Menurut warga, itulah kenapa perjudian di tempat itu bisa selalu aman-aman saja. Ketika saya konfirmasi kebenarannya pada pihak sektor kepolisian setempat, polisi yang saya tanya menjawab bahwa ia tidak memiliki kewenangan untuk menjawab pertanyaan yang saya ajukan terkait maraknya perjudian itu.

Di desa itu, dan mungkin juga di desa lain atau bahkan di kota-kota besar, perjudian agaknya memang selalu berhubungan erat dengan kebiasaan minum beralkohol. Tetapi di sebuah daerah di kawasan industri di pesisir selatan laut Jawa yang sebagian besar warganya hidup sebagai buruh nelayan - buruh di lautnya sendiri, kedatangan penjudi ke desa mereka juga membawa rejeki. Dengan ramainya perjudian di hari-hari tertentu, warung rokok laris-manis oleh pembeli, dan beberapa warga dapat memanfaatkan tenaganya seperti dengan menjadi tukang parkir. Tradisi minum minuman beralkohol di saat kerja ditambah dengan kebiasaan berjudi sambil menenggak minuman, membuat desa di tepi laut itu dengan sendirinya seperti terlokalisir oleh kebiasaan dan kesenangan yang berkebalikan dengan gambaran moralitas ideal yang dijauhi masyarakat Jawa, dengan "Molimo"-nya: Madat, mabuk, madon, maling dan main. Namun dari penggambaran itu, kita juga setidaknya dapat menangkap suatu pesan, 
bahwa bicara minuman keras tidaklah sesederhana bicara soal baik-buruk.

\section{Alkohol dan Politik}

Pada April 2014, media Tribun Jogja menulis berita ketua Badan Pengawas Pemilu (Bawaslu) Daerah Istimewa Yogyakarta (DIY) sedang menggelar rapat koordinasi dengan Polda DIY dan pengurus Dewan Perwakilan Daerah (DPD) partai politik (Parpol). Mohammad Najib yang kala itu menjabat sebagai ketua Bawaslu menyampaikan keluhan yang banyak diterimanya dari masyarakat. Ia tampak kecewa pada aparat kepolisian yang tidak bertindak tegas terhadap konvoi pemilu di jalanan yang telah membuat resah masyarakat.

"Polisi secara psikologis gak berani menangkap. Lha kalau polisi yang punya pistol saja takut, bagaimana dengan kita. Mereka banyak yang mabok karena minum-minuman keras, ini fakta yang ditemukan panwas di lapangan," kata Najib.

Satu tahun berselang setelah rapat koordinasi itu, pada bulan November 2015, dua orang mahasiswa laki-laki dan perempuan yang sedang mengendarai mobil Toyota Yaris dan melintas di Jalan Damai di Yogyakarta berpapasan dengan konvoi parpol. Mobil mereka disuruh berhenti, penumpangnya disuruh keluar, mobilnya dirusak, kaca dipecah, kap diinjak-injak dan keduanya dipukuli tanpa ada pertolongan. Akibatnya, perempuan yang menjadi korban dari aksi brutal itu menderita luka sobek di sekujur punggungnya, begitu juga dengan si laki-laki, tangan dan jari-jarinya sobek diduga karena menahan serangan benda tajam. Versi dari pihak pelaku kekerasan menceritakan, sebelum kekerasan itu terjadi, mobil yang dikendarai oleh dua mahasiswa itu sempat menyenggol dan membikin jatuh salah satu peserta konvoi. Mobil lalu disuruh minggir, tetapi si pengemudi mobil malah mengepalkan tangan. Akhirnya mobil itupun dihentikan massa yang terlanjur tersulut amarah karena kepalan tangan. Saya sendiri yang ketika itu sempat mendapatkan kiriman video berantai yang merekam aksi brutal terperangah tidak percaya sekaligus geram menyaksikannya. Bagaimana tidak, kekerasan yang telah dilakukan oleh kelompok-kelompok yang menamakan diri sebagai organisasi masyarakat (ormas) tersebut tidak hanya terjadi di Yogyakarta dan bukan hanya sekali, melainkan di banyak tempat berkali-kali dengan cara "mengamuk" yang seragam, sampai membuat lembaga kepolisian tak berdaya melakukan tugasnya.

Tidak lama berselang setelah kejadian itu, seorang aktivis dari Yogyakarta, Elanto, membuat petisi yang menuntut agar pihak Kapolda DIY untuk menghentikan konvoi dan aksi kekerasan massa parpol di Yogyakarta. Petisi tersebut telah ditandatangani oleh 2.887 orang. Artinya, tidak sedikit masyarakat yang mendukung penindakan terhadap konvoi dan kekerasan semacam itu. Menanggapi petisi yang tentu dapat mengganggu stabilitas citra Yogyakarta sebagai Kota Budaya, pada awal bulan Desember 2015, Polda DIY dan mengadakan audiensi dengan Elanto dan kawan-kawan. Dalam audiensi itu, Direktur Intel Polda DIY, Amran Ampulembang mengakui bahwa memang "Banyak ditemukan senjata tajam, alkohol dan miras ketika konvoi dan kami telah mengamankannya”. Pandu, warga dari Gadingan Yogyakarta yang menghadiri audiensi saat itupun juga turut mengutarakan pengalamannya, "Saya melihat saat konvoi ada yang membawa samurai dan itu lolos dari pantauan polisi, dan itu membuat saya resah,” kata Pandu, warga Gadingan Yogyakarta pada audiensi tersebut.

Dari cerita di atas, kita dapat menangkap hal lain tentang hubungan antara minuman beralkohol dan parpol atau ormas yang selama ini tak begitu dijadikan perhatian, apalagi diungkap ke media dalam skala nasional. 
Justru sebaliknya, jika kita mengamati secara jeli, yang ada ialah aksi ormas-ormas yang hampir selalu tampil menggantikan aparat kepolisian dalam melakukan pemberantasan minuman keras, merazia tempat pelacuran, dengan cara-cara yang tak jarang menggunakan kekerasan. Memamerkan kekuasaan. Dalam peristiwa itu, keberadaan aparat kepolisian tentu meninggalkan pertanyaan tersendiri: dimanakah mereka ketika aksi-aksi kekerasan komunal yang dilakukan oleh ormas-ormas parpol menimbulkan jatuhnya korban? Daftar korban akibat perbuatan ormas semacam ini tidak sedikit. Tetapi cukuplah cerita di atas menggambarkan bagaimana semangat brutalitas dan kedekatannya dengan minuman beralkohol menubuh dalam politik? Dalam konteks itulah, minuman beralkohol tidak saja berfungsi untuk membuat mabuk orangperorang, tapi jangan-jangan juga telah menjadi kendaraan politik untuk memobilisasi massa supaya kampanye menjelang pemilihan umum dapat mengumpulkan massa sehingga agenda dapat berjalan sesuai dengan apa yang dibayangkan oleh partai politik. Tentu diperlukan riset mendalam untuk menjawabnya.

\section{Pelarangan atau Pembunuhan?}

Berbicara perihal Indonesia, manusia dan minumannya, saya teringat tesis pertama Mochtar Lubis tentang ciri Manusia Indonesia. Ketika melihat kenyataan yang ada, saya menjumpai betapa kemunafikan membayangi wajah lembaga yang membolehkan minuman beralkohol asal luar negeri masuk ke Indonesia, sementara di saat yang sama melarang habis-habisan minuman produksi lokal asal negeri sendiri. Tentu tulisan ini tidak bermaksud masuk ke dalam persoalan moralitas dalam konsumsi minuman beralkohol. Tetapi lebih pada sejauh manakah lembaga berwenang dan para pemangku kebijakan mengambil sikap adil dan beradab dalam menerapkan pengaturan minuman beralkohol?

Untuk menguji efektifitas regulasi minuman beralkohol dijalankan, saya tidak akan sedikitpun membandingkan kebijakan di negara-negara lain mengenai pengaturan peredaran dan konsumsi minuman beralkohol yang jelas tidak mungkin diperbandingkan karena perbedaan geografi kultural dan politik yang tidak dapat dipukul rata. Alih-alih melihatnya melalui perspektif perbandingan semacam itu, dari cerita kaum muda di masamasa SMA, atau juga penuturan seorang nelayan di pesisir selatan Jawa Tengah yang telah disampaikan di bagian sebelumnya, dapat ditarik hipotesa yang menunjukkan bahwa justru pada gambaran kehidupan sehari-hari itulah terlihat efektifitas regulasi minuman diterapkan.

Seperti diketahui di berbagai pemberitaan media dewasa ini, pendisiplinan terhadap peredaran minuman beralkohol oleh beragam lembaga telah dilakukan dengan banyak cara, dari melakukan razia minuman beralkohol impor tanpa ijin hingga razia lapak-lapak kecil pedagang minuman yang dapat ditemukan di setiap daerah di seluruh Indonesia. Bahkan tidak sedikit pihak berwenang yang kemudian memanfaatkan momen tersebut untuk mencari untung. Majalah Tempo mencatat (07/12/14), pada akhir bulan Oktober penyidik Bea dan Cukai membongkar penyelundupan 24 kontainer berisi minuman alkohol ilegal yang disiapkan untuk persediaan tahun baru dengan total senilai 52 miliar. Penyelundupan dilakukan dengan melibatkan orang dalam yang ditengarai selama ini menjadi beking barang ilegal dengan membanderol jasa sejumlah Rp 500-800 juta per kontainer. Melalui beking itulah barang masuk tanpa melewati border resmi, melainkan diangkut dengan menggunakan kapal-kapal kecil menyusuri sepanjang pantai pesisir timur Sumatra dan Kalimantan (baca: Jalur Orang Dalam Miras Selundupan dan Bisnis Gurih 
Miras Ilegal). Bandingkan peristiwa semacam itu dengan aksi penggrebekan yang dilakukan terhadap pedagang minuman kecil di banyak tempat yang bahkan omsetnya tak sampai ratusan juta tetapi framming pemberitaan oleh media mengalahkan berita selundupanselundupan senilai puluhan dan bahkan mungkin ratusan miliar rupiah.

Sudah menjadi tradisi dimana setiap rezim yang berkuasa di negeri ini giat melakukan pendisiplinan peredaran minuman beralkohol. Ritual rutin yang digelar setiap tahun misalnya, berita penghancuran ratusan bahkan ribuan botol minuman beralkohol hasil razia di berbagai daerah di Indonesia setiap menjelang bulan suci ramadhan. Ritual penghancuran tersebut hanyalah salah satu cara dari pendisiplinan terhadap peredaran minuman beralkohol, sebuah metode yang tentunya diharapkan dapat menghilangkan atau paling tidak mengurangi jumlah peminum minuman beralkohol. Namun jika diamati dengan lebih jeli, ritual menjelang bulan puasa itu justru menyisakan pertanyaan tersendiri: Apakah selama ini para pemangku kebijakan benarbenar serius hendak melenyapkan peredaran minuman beralkohol, ataukah hasil razia yang dihancurkan setiap tahun itu hanya sekedar formalitas lantaran terlanjur menjadi sebuah rutinitas? Sebab bila dilihat dari pemberitaan di banyak media tentang konstannya jumlah razia botol minuman yang berhasil dikumpulkan setiap tahun, hal tersebut tidak hanya berarti menunjukkan ada kerja nyata pihak berwenang dalam melaksanakan tugasnya, tetapi juga menandakan kesia-siaan dari penerapan kebijakan yang dijalankan dalam misi memberantas peredaran minuman beralkohol. Lain cerita jika hasil razia botol beralkohol semakin hari semakin susut jumlahnya, karena itu berarti pendisiplinan berjalan efektif. Sampai di sini saja, sudah agak susah menentukan dimana posisi lembaga berwenang dalam diskursus minuman beralkohol, apalagi jika memasuki perbincangan mengenai yang legal dan ilegal dalam peredaran minuman tersebut. Akan tampak betapa absurd kebijakan pemberantasan minuman beralkohol dibuat, sementara lembaga negara juga menerima keuntungan dari perdagangan minuman keras.

Bagi banyak lembaga dan para pemangku kebijakan, dampak dari permasalahan itu mungkin dianggap sepele, tetapi sungguh tidak terbayangkan akibatnya. Dari situ kita menjadi tahu bahwa kemunculan rantai produksikonsumsi minuman oplosan yang telah membunuh ratusan generasi muda dari kelas menengah ke bawah tidak lain adalah hasil dari ketidakmampuan pelakunya mengakses minuman beralkohol yang layak dan aman dikonsumsi, lantaran kebijakan penaikan harga alkohol - yang menurut para pemangku kebijakan akan dapat mengurangi tingginya jumlah konsumsi minuman tersebut tetapi justru melahirkan 'pasar baru' - terlampau mahal bagi mereka. Untuk itulah sekelompok pemuda dari latar belakang menengah ke bawah memilih jenis minuman dengan harga yang lebih murah, sehingga terbukalah secercah peluang bagi beberapa orang membuka usaha minuman oplosan.

Melalui penjelasan ekonomi sederhana, jelaslah bahwa pedagang oplosan tidak lebih dari segelintir orang yang sedang menyiasati pengetatan aturan peredaran minuman dengan menekan tingginya biaya produksi dan mengolah minuman eksperimental hanya supaya tetap mendapatkan pelanggan dan dengan begitu ia bisa tetap memperoleh laba untuk mencukupi kebutuhan sehari-hari. Dalam hubungan antara produsen dan konsumen, didapati simbiosis mutualisme antara pemuda berkantong pas-pasan dan pedagang oplosan - yang mana hal tersebut rupanya lolos dari mata lembaga dan pemangku kebijakan. Entah lolos dari pengamatan, atau menutup mata soal itu. Tetapi yang jelas ratusan generasi muda yang tewas karena oplosan di negeri ini tidak lebih dari anak-anak muda yang ingin bersenangsenang sebagaimana anak muda dari keluarga 
kaya-raya yang hobi dugem ditemani minuman mahal/aman. Dengan kata lain, praktik pelarangan dan pembatasan yang selama ini diterapkan pemangku kebijakan dengan melambungkan harga minuman beralkohol, pada kenyataannya justru melahirkan pasarpasar alkohol baru di luar kendalinya, dan yang paling mengerikan, pasar baru itu telah berhasil membunuh masa depan ratusan generasi muda di negeri ini.

\section{$* * *$}

Pada awal Februari 2016, ketika ngobrol dengan seorang kawan di suatu sore, untuk kesekian kalinya saya mendengar kabar tewasnya 26 pemuda di Yogyakarta setelah minum oplosan. Waktu itu, jumlahnya diperkirakan masih akan bertambah lagi jika melihat kematian di tempat lain yang terusmenerus terjadi dari waktu ke waktu. Mendengar kabar tersebut, saya merasa gerah sendiri karena di dalam pikiran saya tragedi kematian (kalau tak boleh disebut sebagai genosida akibat kebijakan salah-kaprah) akibat minuman alkohol oplosan itu tidaklah terjadi begitu saja, karena nyatanya tragedi itu masih terus saja terjadi rutin dari tahun ke tahun. Apalagi kematian akibat minuman oplosan tersebut sangat kontras dengan cerita minuman yang selama ini mentradisi di beberapa kelompok masyarakat di Indonesia, sebagaimana yang telah tergambar pada awal tulisan ini.

Melalui sumber data yang melimpah di media internet, di mana peristiwa sehari-hari yang telah diberitakan tersimpan dengan baik, saya menghimpunnya untuk mengetahui gambaran tentang berapa banyak kematian akibat minuman oplosan itu dari tahun ke tahun. Dimulai pada perambahan yang saya temukan dalam berita di hari Jumat 16 Januari 2009, 14 orang di Semarang tewas berturut-turut setelah minum alkohol oplosan gingseng yang berkomposisi alkohol, air gula, gingseng, telur, madu, susu dan campuran lain. Selanjutnya pada bulan Mei masih di tahun yang sama, di Tegal Jawa Tengah 22 dikabarkan orang tewas sehabis minum minuman oplosan. Sepanjang tahun 2010, Kepolisian Daerah Jawa Tengah mencatat ada 63 warga tewas karena minuman oplosan. Pada bulan Maret 2011, di Semarang 10 warga tewas seusai minum oplosan. Januari 2012, 5 warga Blitar tewas setelah menenggak minuman oplosan. Pada tahun yang sama di Bali, sepanjang bulan September dikabarkan 5 orang tewas seusai minum oplosan arak, sementara 15 orang lainnya menjalani perawatan. Bulan November 2013 lalu, seusai minum alkohol oplosan 9 orang tewas di Purworejo. Di Jawa Barat sepanjang tahun 2014, 81 warga tewas karena oplosan, menyusul pada tahun berikutnya 52 orang meninggal dengan sebab yang sama. Di Sumedang pada tahun 2014, 106 orang menjadi korban alkohol oplosan dan 7 di antaranya tidak dapat diselamatkan. Juni 2015 di Grobogan 4 orang tewas karena menenggak oplosan. Pada bulan September 2015, 4 nyawa melayang di Surabaya karena hal yang sama. Memasuki bulan Februari 2016, di Malang 3 orang tewas dan 1 kritis setelah menenggak oplosan. Dan di Daerah Istimewa Yogyakarta, pada bulan yang sama, 26 pemuda yang sebagian besar adalah mahasiswa tewas setelah minum oplosan, sebagaimana kabar yang diceritakan oleh kawan saya.

Peristiwa naas yang terus terjadi dari tahun ke tahun itu membuat saya bertanya-tanya, bagaimana mungkin itu bisa terjadi? Benarkah mereka yang telah tewas menenggak minuman oplosan sama sekali tidak tahu-menahu akan bahaya yang dihadapi saat lebih memilih membeli minuman oplosan daripada minuman yang ada label departemen kesehatannya? Ataukah terdapat hal lain yang membuatnya 'mau tidak mau' membeli minuman yang sudah jelas-jelas berbahaya dikonsumsi? Pertanyaan demi pertanyaan yang bermunculan di benak saya itu tak ayal juga membuat saya mempertanyakan lebih jauh, dimanakah sebenarnya peran negara dalam diskursus ini? Apakah negara, melalui lembaga-lembaga yang berwenang telah 
berusaha mengantisipasi tragedi itu, atau justru sebaliknya?

\section{Simpulan}

Uraian di atas hanyalah sekelumit dimensi lain ketika membicarakan minuman beralkohol. Tentu saja ulasan di atas tidak akan sebanding dengan ratusan kematian yang terus terjadi dari tahun ke tahun. Dan kematian-kematian itu tentu saja tidak bisa hanya dilihat sebagai angka. Di baliknya ada kehidupan, harapan dan juga cita-cita yang mestinya masih panjang terbentang tetapi terpotong lantaran Jack Daniels dan Jagermeifter harganya mahal. Alih-alih menutup tulisan ini dengan sebuah kesimpulan, saya ingin mengakhirinya dengan pertanyaan: Apakah lembaga yang berwenang dan para pemangku kebijakan akan tetap bersikeras melanjutkan pengaturan minuman beralkohol dengan cara serupa yang justru memicu munculnya pasar baru oplosan dan membunuh ratusan warga lalu menanggapinya dengan kata usang yang diulang-ulang, “..masih rendahnya kesadaran masyarakat akan bahaya alkohol”, ataukah mengubah aturan dengan lebih adil, beradab dan masuk akal? Sebab, banyaknya generasi muda yang menggelepar setelah minum oplosan tidak bisa dianggap wajar hanya karena menenggak regulasi minuman yang bias kelas.

\section{Daftar Pustaka}

Anderson, Benedict R.O.G. (1983). "Old State New Society: Indonesia's New Order in Comparativee Historical Perspective”, Journal of Asian Studies, Vol.XLIII, No.3, May 1983. Pp.477-496.

Drake, Earl. (2012). “Gayatri Rajapatni: Perempuan di Balik Kejayaan Majapahit”. Yogyakarta: Penerbit Ombak.

Foucault, Michel. (2002). "Kegilaan dan Peradaban”. Yogyakarta: Ikon Teralitera. Haryatmoko. (2016). "Membongkar Rezim Kepastian: Pemikiran Kritis Post-Strukturalis”. Yogyakarta: PT.Kanisius.
Pradipha, F Chrysnha. (2014). “Gambaran Budaya Timur-Barat dalam Cerpen Seribu Kunangkunang di Manhattan Karya Umar Kayam: Tinjauan Sosiologi Sastra”. Skripsi Jurusan Sastra Indonesia. Universitas Sebelas Maret Surakarta: Fakultas Sastra dan Seni Rupa.

Supriyanto, Henri. (2012). "Hidup Hanyalah Persinggahan Sebentar untuk Minum”. Dipublikasikan oleh Srinthil, Media Perempuan Multikultural, di laman www.srinthil.org. (yang ini, website juga sudah off, tapi sumber tulisan masih bisa diakses di laman http://www.desantara.or.id/2012/01/urip-ikumung-mampir-ngombe/

Prasetya, Heru. (2012). “Arak, Mabuk, dan Perempuan di Dunia Persilatan”. Dipublikasikan oleh Srinthil, Media Perempuan Multikultural, https://heruyaheru.wordpress.com/2012/02/24/ arak-mabuk-dan-perempuan-di-duniapersilatan/

Utomo, Paring Waluyo. (2012). "Tradisi Tuak dan Peran Perempuan Tuban”. Dipublikasikan oleh Srinthil, Media Perempuan Multikultural, di laman www.srinthil.org.

Cribb, Robert. (1988). "Opium and the Indonesian Revolution”. Cambridge University Press. Pp.701-722.

Lohjati, Sumirat. (2011). "The Art of Drinking: Sejarah Minuman dan Keberminuman”. Sleman: Immortal Publisher.

Kasijanto Sastrodinomo. (2006). "Mabuk-mabukan dalam Sejarah”. Kompas, 18 Maret 2006, hlm: 42.Majalah Tempo Edisi Khusus Kuliner Indonesia, 1-7 Desember 2014. "Jalur Orang Dalam Miras Selundupan” dan “Bisnis Gurih Miras Ilegal”. Hal: 178-182.

Catatan lapangan, Juni-juli 2015 di Cilacap.

Cerita pendek Umar Kayam "Seribu Kunangkunang di Manhattan”, diakses di www.luqmansastra.blogspot.co.id pada Minggu, 21 Februari, pukul 13:00.

---“Ahok: DKI Punya Saham di Perusahaan Bir dari Tahun 1970, Kenapa Baru Ribut Sekarang?”. Kompas, Kamis 9 April 2015. diakses di www.megapolitan.kompas.com pada Senin 22 Februari, pukul 19:00.

---“Bawaslu DIY: Polisi Tidak Berani Tertibkan Konvoi”.Tribun Jogja, Jumat 4 April 2014. 
diakses di www.jogja.tribunnews.com pada Selasa 23 Februari, pukul 14:00.

---“Dua Korban Pemukulan Salah Satu Parpol di Jalan Damai Masih Jalani Perawatan

Intensif”.Tribun Jogja, Minggu 22 November 2015 diakses di www.jogja.tribunnews.com pada Selasa 23 Februari, pukul 14:00.

---_Ini Sikap Polda DIY terhadap Petisi Elanto”, Koran Opini, Senin 7 Desember 2015 diakses di www.koranopini.com pada Selasa 23

Februari, pukul 14:00. 